\title{
PENTECOSTALS AND CHARISMATIC PROTESTANTS IN THE REPUBLIC OF KOMI AND NENETS TUNDRA
}

\author{
Art Leete, Piret Koosa, Laur Vallikivi
}

Between 2010 and 2012, an extended team of scholars studied contemporary Protestant groups in Russia. The project was labelled Center for the Study of Pentecostal and Charismatic Movements in Russia ${ }^{1}$ (CSPCMR) and was led by Aleksandr Panchenko from the European University in Saint Petersburg and Patrick Plattet from the University of Alaska Fairbanks. Besides Russia and the USA, scholars from Ireland, the United Kingdom, France, and Estonia were involved in this collaborative research effort. The host institution of the project was the European University in St. Petersburg.

The aim of the project was to analyse the Protestant-charismatic (P/c) Christianity in various regions of post-Soviet Russia. The project proceeded from the notions concerned with global effects of the rapid extension of P/c Christianity in the contemporary world. In the anthropology of Pentecostalism, problems of continuity and change, globalisation and indigenisation, preservation of prePentecostal ontologies, creating the new morality and approaches to economy and politics have been discussed (Coleman 2000; Robbins 2004a, 2004b). The Estonian team's specific task was to analyse contemporary Protestant missions and churches in the north-eastern corner of European Russia, in the Republic of Komi and the European Nenets tundra.

The first Pentecostal churches were established in Russia in the 1920s. Beginning in the 1930s, Pentecostals were persecuted and during the anti-religious campaign of the 1950s and 1960s they became a special target for Soviet repressions. Pentecostals were accused of fanaticism (a stereotype mainly based on the practice of 'speaking in tongues') and even ritual murder. As a result, most Pentecostal churches in Russia continued to exist without official registration (Lunkin 2004; Nikolskaya 2009; Panchenko 2013). Beginning in the late 1980s, numerous foreign Pentecostal missions started to proselytise in the 
post-Soviet territories and new ritual elements and ideologies were promoted (emotional praise, rock music, mass healing, and other signs of spiritual gifts and the 'gospel of prosperity').

Our project members studied contemporary Evangelical, Pentecostal and Charismatic churches in Russia by doing multi-sited ethnographic fieldwork. We aimed to explore different understandings of religious life at official, group, and individual levels. Also, the connections of Pentecostal and charismatic movements with other religious phenomena were under study. Field studies were conducted in the city of Novgorod, the Republic of Komi, Arkhangelsk oblast, Western Siberia, Chukotka, Kamchatka Peninsula, the Khabarovsk region, Krasnoyarsk Krai, and Altai.

The Estonian research team conducted fieldwork among Protestant communities in the Republic of Komi and the Nenets Autonomous Region: the Church of Christ the Saviour (Rossiiskii soiuz evangel'skikh khristian-baptistov, Tserkov' Khrista Spasitelia) and Komi Evangelical Church (KEC, Komi Khristianskaia Tserkov' Evangel'skoi Very) in Syktyvkar, Evangelical community in the village of Don (Donskaia Khristianskaia Obshchina) and Pentecostal mission (Russian Church of Christians of Evangelical Faith (RCCEF), Rossiiskaia tserkov' khristian very evangel'skoi) in the Kulömdin district and in the Vorkuta area, regional central mission of RCCEF in Vorkuta, and unregistered Baptists in the Vorkuta region, the Republic of Komi.

From a global perspective, P/c Christianity has been depicted as increasingly replicating itself in different societies but also adapting to cultures into which these movements have been introduced (Robbins 2004b: 129). Russia is a specific region for this interplay of the global and the indigenous. The Russian Orthodox Church (ROC) dominates the public religious sphere. This firmly established preference makes it complicated for $\mathrm{P} / \mathrm{c}$ movements to introduce their globalist agenda but also obstructs their indigenisation to a certain extent. We searched for answers concerning problems of the degree of universalisation or localisation of $\mathrm{P} / \mathrm{c}$ communities' religious practices, continuities with local religious traditions, and specific 'Russian' features of Pentecostalism.

We discovered that in the churches under study local cultural peculiarities have been taken into account to differing degrees. In the countryside, $\mathrm{P} / \mathrm{c}$ churches adapt themselves more to traditional vernacular religiosity and adopt local features. Urban missions apply more strictly their globalist agenda but diverse strategies can be traced also inside the same mission.

The RCCEF Pentecostal Church in Vorkuta unites the intellectualising and emotionalising tradition of Russian Protestantism. On the one hand, the intellectual understanding of the Bible is preached as central. A service - especially in the main church of the union - might be carried out without glos- 
solalic prayers. The stress is on reading and explicating God's Word, singing, general prayers. Divine gifts are usually not publicised. Some practices and ideas exemplify tensions between the Nenets vernacular approach to religion and the Pentecostal ideology. The converted Nenets try to adapt to the Pentecostal agenda but a few traditional religious practices remain hidden from the missionaries. We also studied another branch of the same Pentecostal mission in the Kulömdin district. This mission united a very small, unstable and scattered rural community. An indigenous Komi missionary, born in Kulömdin, had a rather indigenised social agenda and he was a big enthusiast of glossolalia.

The KEC in Syktyvkar was established in the Soviet period (in the 1950s). During the post-Soviet era the church has become influenced by the Pentecostals and recognises glossolalia and the charismatic style of church services. Services in the KEC are always conducted in the Komi language, and an ethnic agenda is stressed by different cultural and social initiatives (initiating translation of the Bible into Komi, organising radio shows in Komi, and demonstrating closeness to vernacular religiosity by using Orthodox symbols).

Rupture and discontinuity with the past are the usual qualities of the P/c movements' discourse (Robbins 2004b: 127). In Russia the discourse of rupture functions in a specific way. Our project was especially interested in the idea of 'prosperity gospel' in a post-Soviet capitalistic context, and also explored how both 'godly' and 'ungodly' domains of life are constructed in P/c discourse and practice in Russia.

Prosperity gospel cannot be found in Komi villages as this is in sharp contrast with the local social reality. Anyway, the believers do not condemn wealth in principle and moderately encourage economic success. Don Evangelicals presented to us a middle-aged woman who managed to build a small house after joining the Protestant community, and a man who joined the group and then managed to start a business as a sawmill owner (the only private enterprise in the village). In the tundra, however, the prosperity gospel is totally absent.

The idea of rupture plays an important role among the Vorkuta Pentecostals. A complete break with the past has to be enacted both in words and in deeds. A Pentecostal missionary explained how the use of alcohol and idolatry are tightly related to each other and how they lead many to commit suicide, both physically and spiritually (Vallikivi 2011).

Our task was also to pay attention to collectively maintained plausibility structures that serve as tools for constructing and preserving a unique religious world. Personal narratives reflect key categories, modes of identity formation and forms of religious practices of church communities. Religious life of the $\mathrm{P} / \mathrm{c}$ communities is also dependant on the previous religious and social background of their members (see Leete \& Koosa 2012). 


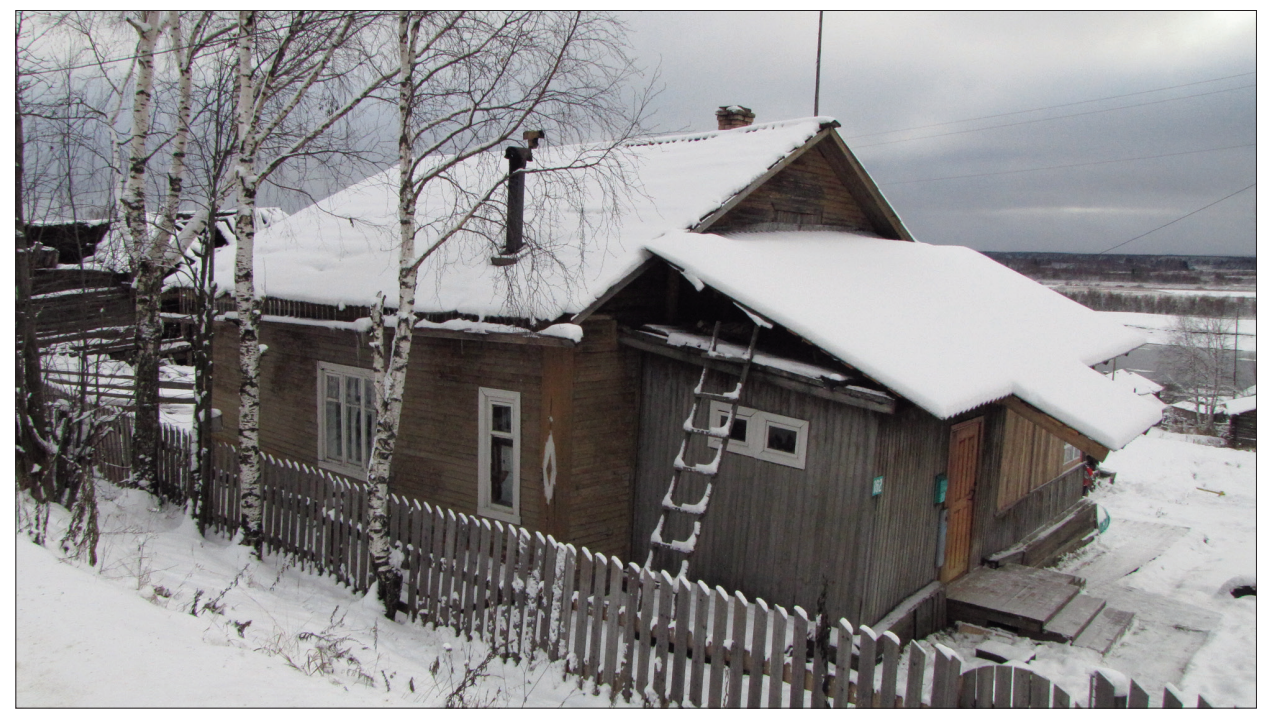

Pentecostals' house of worship, also missionary's home, in Ust-Kulom (Kulömdin). Photograph by Art Leete 2009.

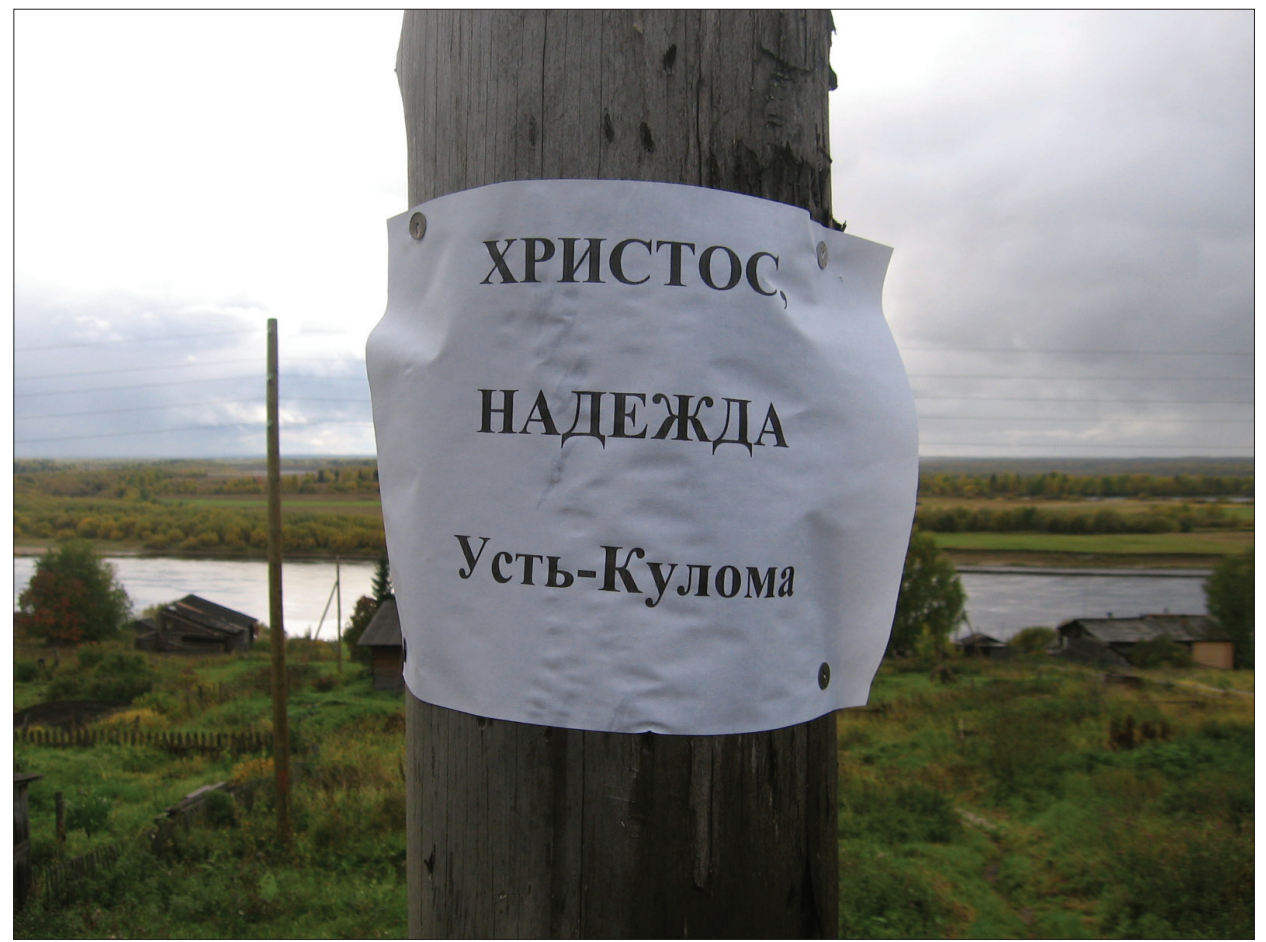

Charismatic Protestants' poster in Ust-Kulom settlement, reading: "Christ is hope for Ust-Kulom". Photograph by Piret Koosa 2008. 
Testimonials about how one came to God constitute an important genre through which people express their religious identity. These narratives are supposed to bring new people to God and to confirm the believer's experience. Conversion narratives demonstrate that somebody has obtained a common vocabulary and mode of talking about spiritual matters. Excellent knowledge of the Bible and the ability to quote it by heart is highly valued. A pastor from Vorkuta described how at one point 'tongues' engulfed him. His spiritual baptism preceded his intellectual understanding of the biblical message. While evangelising among the illiterate Nenets, the Pentecostal missionaries adapt their rhetoric about the importance of reading the Bible. They stress that the Holy Spirit allows the Nenets converts to be saved without them being able to read.

Opposition from the ROC to Evangelical churches is one important factor prompting cooperation between different Protestant denominations. The Don community, the Komi Evangelical Church, and the Baptist Church in Syktyvkar hold active connections with churches abroad, and such international relations give an eminent reason to place Evangelicals under the contempt of the patriotic discourse (Koosa 2013). While the congregants in Syktyvkar can enjoy their close relationship to the Evangelical church relatively peacefully, it is much more complicated in rural areas. The majority of the people with a strong preference for Orthodoxy are continually challenging the congregations' right to exist.

In the competition between Baptists and Pentecostals for souls, Baptists have been far more successful in the tundra. The small amount of Nenets converts cannot decide where to place their loyalty. From time to time, the Pentecostals visit the Baptist prayer house as well. The Pentecostal missionary does not object to this. Instead, he encourages Nenets families to carry out services together with Baptist families in the tundra. The main Baptist missionary was less eager to cooperate, claiming that Pentecostals were fake Christians who were possessed by Satan. For instance, after the Baptist pastor learned that a Nenets family had been baptised by the Pentecostals, he stopped visiting them.

The Unregistered Baptists attribute two kinds of problems to the Pentecostals. First, the latter are too 'modern' in their outlook and conduct. Second, they speak in tongues without knowing what they are doing, insisting that Paul urged to interpret what was told in foreign tongues. Furthermore, they say that this was highly unlikely that after the early apostolic church this gift was actually active. In comparison to the Unregistered Baptists, the Registered Pentecostals (like the Registered Baptists) are somewhat more liberal and less concerned about the avoidance of worldly attractions. They are not that strict in their dress code, nor do they prohibit watching TV. In addition, they do not stress to the same extent their unique historic role in the development of God's church on earth. 
In the Don congregation, the weekly Sunday service is the central regular ritual. Although the pastor emphasises its free form of conduct, it has developed a certain structure and an order of the parts, which is followed by communal tea drinking. The congregation is imagined as a family, and close relations are considered essential to live a truly Christian life. The idea is that it is very hard if not impossible to be a true Christian and learn Christian love in solitude.

One of the most anticipated parts of the service is the singing of religious hymns - several current members of the Don group assert that the joyful songs were the incentive for why they started to visit the services. Some believers create their own songs to praise god. Singing constitutes a way to express one's experience of the sacred, of personal transformation, and the need to share it with others.

Protestant churches in the Republic of Komi considerably adapt themselves to the socio-political reality in the region. They must accept that the local religious field is dominated by the ROC. Anyhow, this adaptation does not necessarily mean the acceptance of all demands proposed by the local ROC bishop and clerics in the districts of the republic. In finding a proper line of action, strategies may vary considerably among different Protestant churches and communities.

Protestant churches adopt some global features of $\mathrm{P} / \mathrm{c}$ missions everywhere in the Republic of Komi and Nenets tundra. These necessary indicators of proper religious behaviour include a need for reading the Bible and demonstrating one's faith by good deeds. The usual global social indicators of P/c movements (e.g. ideology of prosperity) are modestly and fragmentarily expressed, but nonetheless significant, as they demonstrate that Protestants encourage people to improve their lives.

The religious leaders of $\mathrm{P} / \mathrm{c}$ Christians tolerate the local historical features of religiosity more readily when the social surrounding strongly supports orthodox religious conduct. It is also possible to observe a few significant local peculiarities in the agenda of $\mathrm{P} / \mathrm{c}$ movements. They may accept that for a majority of local people, their church has a non-spiritual role in village life (as Don Evangelicals admit concerning the implementation of their social programmes; see Koosa \& Leete 2014). The Komi Evangelical Church has adopted a rather strong ethnic agenda that they suppose to be significant for the entire Komi society.

Our comparative study revealed that Baptists are less ready to tolerate spiritual compromises with other churches as well as vernacular religious traditions. Also, in Syktyvkar and Vorkuta, the most important administrative and religious centres of the Republic of Komi, churches tend to be stricter in following their own agenda. Missionaries' individual understanding of faith 
plays a more important role in the case of independent churches or missions that are launched far from big administrative and religious centres.

The study of Protestants in the north-eastern corner of European Russia can be developed further by gathering more reliable statistical data, improving comparative methodology and mapping a bigger number of Protestant communities during future field studies. As the region represents an intriguing case for elaborating investigations on the local peculiarities of Protestant development in the Russian North, this study serves as a basis for forthcoming research efforts. ${ }^{2}$

\section{NOTES}

1 The project was part of the Pentecostal and Charismatic Research Initiative, coordinated by the Center for Religion and Civic Culture at the University of Southern California and supported by the grant of the John Templeton Foundation (see also the web page of the Pentecostal and Charismatic Research Initiative: http://crcc.usc.edu/initiatives/ pcri/).

2 These new ongoing research projects (Estonian Reseach Council grants PUT590 and PUT712) are related to the study of Protestantism and animism in the same region.

\section{REFERENCES}

Coleman, Simon 2000. The Globalisation of Charismatic Christianity: Spreading the Gospel of Prosperity. Cambridge: Cambridge University Press.

Koosa, Piret 2013. Sowing the Seeds of Faith: A Case Study of an American Missionary in the Russian North. Journal of Ethnology and Folkloristics, Vol. 7, No. 1, pp. 31-48. Available at http://www.jef.ee/index.php/journal/issue/view/12, last accessed on June 29, 2015.

Koosa, Piret \& Leete, Art 2014. Serving God by Being Neighbourly: Komi Protestants and Local Community Initiatives. Suomen Antropologi. Journal of the Finnish Anthropological Society, Vol. 39, No. 2, pp. 39-57. Available at http://www. academia.edu/9385561/Serving_God_by_Being_Neighbourly_Komi_Protestants_ and_local_community_initiatives, last accessed on June 29, 2015.

Leete, Art \& Koosa, Piret 2012. The Churches Were Opened and Lots of Missionaries Arrived: Dialogue between Komi Identity and Faith. Folklore: Electronic Journal of Folklore, Vol. 51, pp. 171-190. doi:10.7592/FEJF2012.51.leete-koosa.

Lunkin, Roman 2004. Traditional Pentecostals in Russia. East-West Church \& Ministry Report, Vol. 12, No. 3, pp. 4-7. Available at http://www.eastwestreport.org/articles/ ew12302.html, last accessed on June 29, 2015.

Nikolskaya 2009 = Nikol'skaia, Tat'iana. Russkii protestantizm i gosudarstvennaia vlast' v 1905-1991 godakh. [Russian Protestantism and State Power from 1905 to 1991.] Sankt-Peterburg: Izdatel'stvo Evropeiskogo universiteta v Sankt-Peterburge. 
Panchenko, Aleksandr 2013. "Sviashchennyi teatr", tonkosti morali i obriady perekhoda: antropologiia global'nogo khristianstva v sovremennoi Rossii. [“The Holy Theatre", Nuances of Morality and Rituals of Transition: Anthropology of Global Christianity in Contemporary Russia.] Antropologicheskii Forum, Vol. 18, pp. 215-222. Available at http://anthropologie.kunstkamera.ru/files/pdf/018/ panchenko_preface.pdf, last accessed on June 29, 2015.

Robbins, Joel 2004a. Becoming Sinners: Christianity and Moral Torment in a Papua New Guinea Society. Berkeley: University of California Press.

Robbins, Joel 2004b. The Globalization of Pentecostal and Charismatic Christianity. Annual Review of Anthropology, Vol. 33, pp. 117-143. http://dx.doi.org/10.1146/ annurev.anthro.32.061002.093421.

Vallikivi, Laur 2011. What Does Matter?: Idols and Icons in the Nenets Tundra. Journal of Ethnology and Folkloristics, Vol. 5, No. 1, pp. 75-95. Available at http://www. jef.ee/index.php/journal/issue/view/9, last accessed on June 29, 2015. 